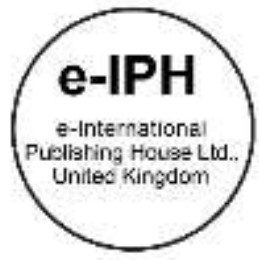

\title{
Visual Effect of Modern Buildings on a Traditional Japanese Garden
}

\author{
Buket Senoglu ${ }^{1}$ Hilmi Ekin Oktay², Isami Kinoshita ${ }^{1}$ \\ 1Environmental Science and Landscape Architecture, Graduate School of Horticulture, Chiba University, Japan \\ 2Landscape Architecture, Architecture and Design Faculty, Van Yuzuncu Yil University, Turkey \\ senoglubuket@gmail.com; ekinoktay@yyu.edu.tr, isamikinoshita@faculty.chiba-u.jp \\ Tel: +8109060495018
}

\begin{abstract}
Even though heritage gardens have been preserved successfully in Japan, these gardens, especially the ones in Tokyo, have been surrounded by modern high-rise buildings that have entered the scenery of the gardens dramatically. This situation has become an issue from the perspective of cultural heritage preservation. This paper aimed to define the effect of modern buildings on a Japanese heritage garden called Hama-rikyu Gardens in the context of user perception by a questionnaire on site. Results indicated that the modern buildings should be eliminated from the scenery of the garden in the future since the participants preferred unspoiled views.
\end{abstract}

Keywords: Landscape Design; High-rise building; Japanese Garden; User Preference

eISSN: 2398-4287 @ 2018. The Authors. Published for AMER ABRA cE-Bs by e-International Publishing House, Ltd., UK. This is an open access article under the CC BYNC-ND license (http://creativecommons.org/licenses/by-nc-nd/4.0/). Peer-review under responsibility of AMER (Association of Malaysian Environment-Behaviour Researchers), ABRA (Association of Behavioural Researchers on Asians) and cE-Bs (Centre for Environment-Behaviour Studies), Faculty of Architecture, Planning \& Surveying, Universiti Teknologi MARA, Malaysia.

DOI: https://doi.org/10.21834/e-bpj.v3i8.1393

\subsection{Introduction}

Parks and gardens especially historical heritage ones in urban environments are an essential component of modern cities (Thani et al., 2015; Sakip et al., 2015). There are plenty of research on benefits of green areas (Omar et al., 2015) and they had shown consisting findings that natural environments are preferred over built environments (Kaplan and Kaplan, 1989), and the existence of green spaces like parks and gardens in urban areas has a great importance for city inhabitants since these spaces have restorative effect on humans (Kaplan et al. 1998). Previous studies have shown that being in contact with nature helps to avoid stress which is caused by urban life and to improve human well-being both in mental and physical ways (Razak et al., 2016; Thani et al., 2016; Kaplan and Kaplan, 1989). However, recent urbanization phenomena with the effect of global capitalism have affected many aspects of landscape structure and overall human condition consequently (Othman et al., 2015). In response to economic, industrial and social changes, construction of skyscrapers has become a global phenomenon, and tall buildings started to shape the skylines (Rahman et al., 2015). As the shape of the cities has started to be vertical and dense, social bonds and place identity have started to decrease, and this situation has become an issue for both environmental aesthetics, environmental psychology and environmental behavior which are strongly related (Ujang et al., 2015; Othman et al., 2015).

Currently being one of the tallest cities in the world, Tokyo has faced a rapid vertical growth due to complex social, legal, economic and political conditions and its skyline and identity have been reshaped by high-rise buildings. This situation has caused the current condition of city's image that is often criticized by scholars as 'chaotic morphology' since high-rise buildings retrofitted into the existing urban fabric despite minimal planning strategies (Perez, 2014). Therefore, Tokyo has become a subject for the studies trying to find

eISSN: 2398-4287 (C) 2018. The Authors. Published for AMER ABRA cE-Bs by e-International Publishing House, Ltd., UK. This is an open access article under the CC BYNC-ND license (http://creativecommons.org/licenses/by-nc-nd/4.0/). Peer-review under responsibility of AMER (Association of Malaysian Environment-Behaviour Researchers), ABRA (Association of Behavioural Researchers on Asians) and cE-Bs (Centre for Environment-Behaviour Studies), Faculty of Architecture, Planning \& Surveying, Universiti Teknologi MARA, Malaysia.

DOI: https://doi.org/10.21834/e-bpj.v3i8.1393 
solutions for the problems caused by high-rise buildings (Prompayuk and Chairattananon, 2016). It has been proven that the high-rise buildings cause a sense of oppression in urban space for city dwellers and in the same time, they destroy some pleasant urban forms (Asgarzadeh et al., 2012). However, Tokyo is not just a modern city with high-rise buildings but a historic city that has been the capital of the country since the Edo period. Thus, the city has many heritage sites from earlier periods which facilitate recreational amenities in the urban space such as the traditional gardens date back to Edo period (1603-1868).

During Edo period, daimyo (feudal lords) had the prosperity, and they competed to construct large and beautiful gardens at their residences (Shinji, 2015). The gardens of this period were a new prototype with their design features called kaiyu-shiki teien (strolling garden) and Shakkei (borrowed scenery) (Arifin, 1997). These gardens were created with a broad consideration of visual qualities and concentrated on not only internal design but also made use of remote landscapes such as Mt. Fuji, Mt. Tsukuba, ocean, and rivers by incorporating them into the sceneries of the gardens by Shakkei (borrowed scenery) technique. However, with the occurrence of urbanization phenomenon as aforementioned, these gardens have been surrounded by many high-rise buildings and the buildings entered the sceneries of the gardens dramatically. The effect of high-rise buildings on these traditional gardens has become a scientific research question from the perspective of cultural heritage preservation and environmental aesthetics. Since the vision of the surrounding environment is an essential and inseparable part of the heritage gardens, the scenery in the background needs appropriate protection (Lin et al., 2017; Shinobe, 2012).

Cultural landscapes are the most fragile and threatened sites on earth due to rapid social and economic development, and the loss of them would imply the absence of humanity (Türkylmaz, 2016). Therefore, preservation of cultural heritage sites has a great importance since they reflect place identity, sense of place, spiritual connection with the environment and cultural identity. They help to enhance cultural memory, environmental diversity and a society's quality of life (Zakaria et al., 2016; Prompayuk and Chairattananon, 2016; Ginting and Rahman, 2016). Among cultural heritage properties, heritage garden is unique cultural phenomenon and carrier of traditional culture which contains tangible and intangible heritage elements in perfect harmony (Abbas et al., 2016). Traditional daimyo gardens in Japan are too, highly appreciated heritage values not only for the country itself but the whole world so that their proper preservation has great importance. As stated in Venice Charter, the heritage sites must be the object of specific treatment to prevent their integrity and assure that they are apparent and demonstrated in an appropriate feature (Prompayuk and Chairattananon, 2016). Cultural heritage sites and particularly the heritage gardens of Japan have been preserved effectively under the conditions covered by National Cultural Property Protection Act. However, many high-rise buildings have settled down in the surroundings of the gardens since those areas are not covered by the Act (Arifin and Masuda, 1998). The previous studies regarding the issue have demonstrated the negative impact of high-rise buildings on Japanese gardens. Moreover, they stated that the surroundings of the gardens need to be controlled urgently since the original spirit is under the threat of devaluation (Lin et al., 2017; Shinji, 2015; Shinobe, 2012; Koizumi and Ishikawa 2007; Arifin and Masuda, 1997; Shinji et al., 1989). However, most these studies were done with objectivist approaches whereas the research addressing the issue by considering the subjective appraisals of users is still limited (Senoglu et al., 2018; Arifin and Masuda, 1998).

Therefore, this paper aims to define the effect of modern buildings on a traditional Japanese garden in the context of user perception. The objectives of this study are determined as:

- to test whether presence or absence of modern buildings at the surroundings of Hama-rikyu Gardens affects landscape preferences,

- to investigate the influence of landscape features (trees, traditional buildings, water bodies etc.) in the scenery on landscape preferences

\subsection{Methodology}

A psychophysical model that is highly related to environmental behavior approach was determined as the research methodology. Samplings were done for the garden scenes. For the scene sampling, an online survey tool was used to collect the assessments of experts, and an in-situ survey was conducted to collect the assessments of garden visitors.

This study is limited because it only addressed one garden as a case. Therefore, the findings may be insufficient to explain the visual effect of external buildings on the scenery of Japanese gardens in general.

\subsection{Study Area}

Hama-rikyu Gardens located in Tokyo was constructed in Edo period (1603-1868) as a grand-scale stroll type daimyo garden (Figure 1). Shakkei technique was used in the garden so that it had borrowed sceneries of Mt. Fuji, Mt. Tsukuba, Edo (Tokyo) Bay, Boso Peninsula and Shinagawa Bay (Shinji, 2015). These sceneries have disappeared due to the erection of many modern high-rise buildings at the surroundings of the garden. The previous studies regarding the issue revealed the negative impact of the external buildings on the garden's scenery with objectivist approach (Koizumi and Ishikawa, 2007; Shinji et al., 1989). However, since the studies considering the visitors' perception on this issue (Senoglu et al., 2018) is still limited, this garden is thought to be an important research area where the effect of surrounding modern buildings should be investigated in the context of visitor judgments. 


\subsection{Stimuli}

According to Kaplan and Kaplan (1989), there is no significant difference between the results derived by photographs (even if the photographs are black and white) as surrogates for real landscape and the results derived by looking at actual landscapes on the field. Therefore, it was decided to represent the landscapes with photos in this study which let the usage of photo manipulation programs.

Sampling of a site is an important issue in landscape preference studies. Kaplan and Kaplan (1989) have indicated some key criteria to select a sample from an environment. As aforementioned, Hama-rikyu Gardens is a grand-scale garden covering an area of $250,215.72 \mathrm{~m}^{2}$, and high-rise buildings enter the garden's scenery from almost every observation point. Besides, the visual landscape features in scenery would be effective on the preferences so that a careful sampling was needed. Therefore, 92 photos (taken from the garden using a DSLR camera with $10 \mathrm{~mm}$ wide-angle lens mounted on a tripod fitted on $175 \mathrm{~cm}$ height) were assessed by seven experts in spatial design and planning disciplines to achieve the most representative scenes for each category with an objective selection. Experts assessed each photo regarding the dominance level of each landscape element (water, trees, hills, traditional structures, turf and groundcovers, paths, fields and crops, mixed) and conspicuousness level of external buildings by 5-point Likert scale. By the analysis of expert assessments, the five most dominant landscape components were derived (water, trees, traditional structures, paths, fields, and crops). Three photos for each landscape component was selected based on their building ratio in the scenes (one for high ratio, one for moderate ratio, one for low ratio). As a result, 15 photos were selected in total, and they were manipulated by Photoshop CC 2018 to erase the external buildings from sceneries. Finally, 30 photos (15 original, 15 simulated versions) were used for the questionnaire on visitor judgments.

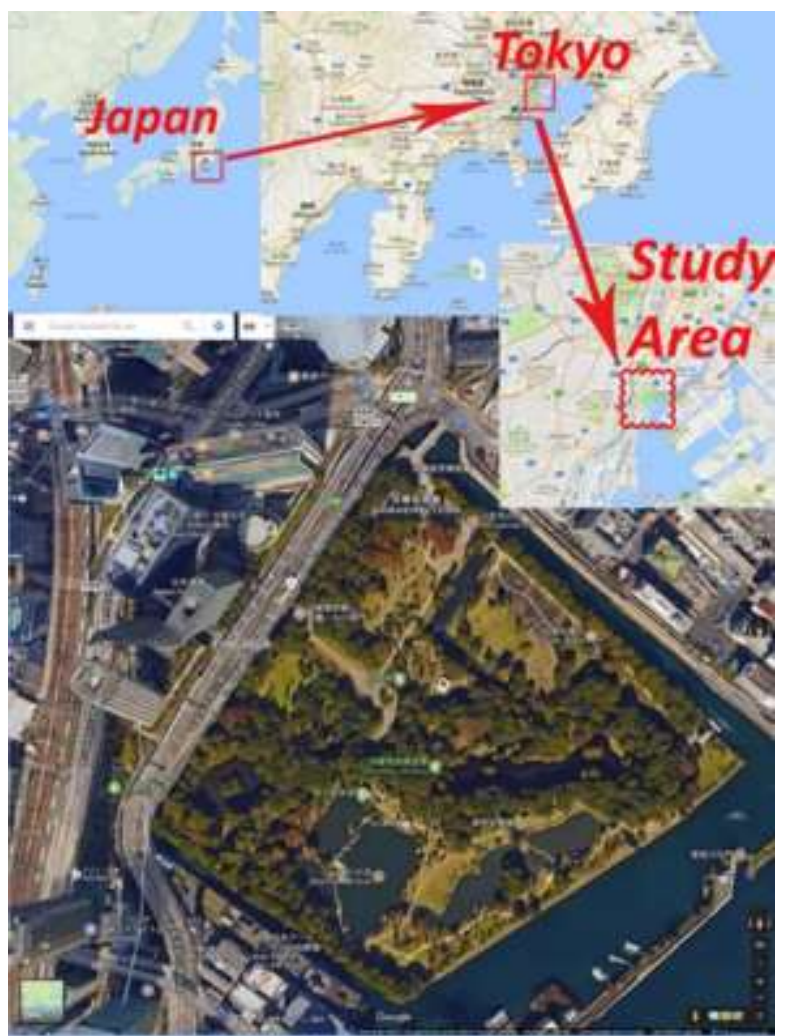

Fig. 1. Study area (Source: Google Maps. 18.09. 2017)

\subsection{Respondents}

The sample size for the respondents was selected on a 95\% confidence level as higher confidence levels can cause Type II error in the statistical analyses of the data. Therefore, the results of the statistical analysis were derived based on the significance level at $p \leq 0.05$.

From 500 questionnaires distributed in the garden, 420 were returned. Respondents voluntarily took part in the study. The instructions were presented in written and oral form (in English and Japanese). Respondents were required to answer the questions after strolling in the garden. On completion, they returned the questionnaire sheets to a survey attendant.

\subsection{Questionnaire Design}

The questionnaire had three parts. The first part was the photo survey in which the 30 photos were placed (four photos on each page). The placement of the photos was done carefully not to affect people's assessment so that no photo pair (original photo and simulated version) was on the same page. Assessments on this part were designed to be done on five variables (how much the scenery is liked and four affective appraisals) on 5-point Likert Scale. The second part of the questionnaire comprised a verbal attitude scale with 22 items to determine the respondents' level of agreement with the propositions about the effect of external buildings on the garden. Finally, 
socio-demographical variables were collected in the third part. The questionnaire was conducted on three consecutive days in March 2018 (March 24, 25, 26).

\subsection{Data Analysis}

All the questionnaires have been coded into the computer. The raw data of the answers to questionnaires has been imported to statistical software called IBM Statistics Package for Social Sciences (SPSS) version 23. Two different data set has been arranged for different statistical analyses. In one version, all answers of the respondents were coded question by question and $420 \times 190$ data matrix was obtained. The other version was arranged to find total preference score for all photos; to compare the preferences for scenes of with building and without buildings; and to find the relationships with other variables. To achieve this aim, the preference scores and four affective appraisal variables for all sceneries were written one under the other and 12600X5 cell data matrix was obtained. Then, other 22 verbal attitude and socio-demographic variables were written 30 times one under the other and 12600X40 cell data matrix was obtained. In the first version, mean preference scores for each photo were calculated; reliability between the variables were found and factor analysis were performed for the preference for each photo. The other data version was used for the comparison of the photos with buildings and without buildings as well as regression analyses. Analysis of variance test was used to compare the photos with buildings and without buildings. Regression analysis was done to find relationships between demographic variables and preferences.

\subsection{Results}

Regarding the aim and objectives, only the results derived from the analysis on the general preferences (liking degree) in the first part of the questionnaire (photo survey) was given in this paper.

\subsection{Mean scores of preferences for scenes}

Figure 2 represents the mean scores of all photos and their sequence. The results showed that the most liked scene (3.68) was one of the simulated photos (without buildings) whereas the least liked scene (2.81) had modern buildings in the background intensely. The sequence indicates that the most preferred top seven photos did not have buildings in their sceneries (Figure 2). In these seven most liked photos, the only original photo (not simulated) was Photo 4, but the building ratio in its scenery was very weak and inconspicuous at all. On the other hand, the least liked three photos at the bottom had the commonality of having buildings in their sceneries.

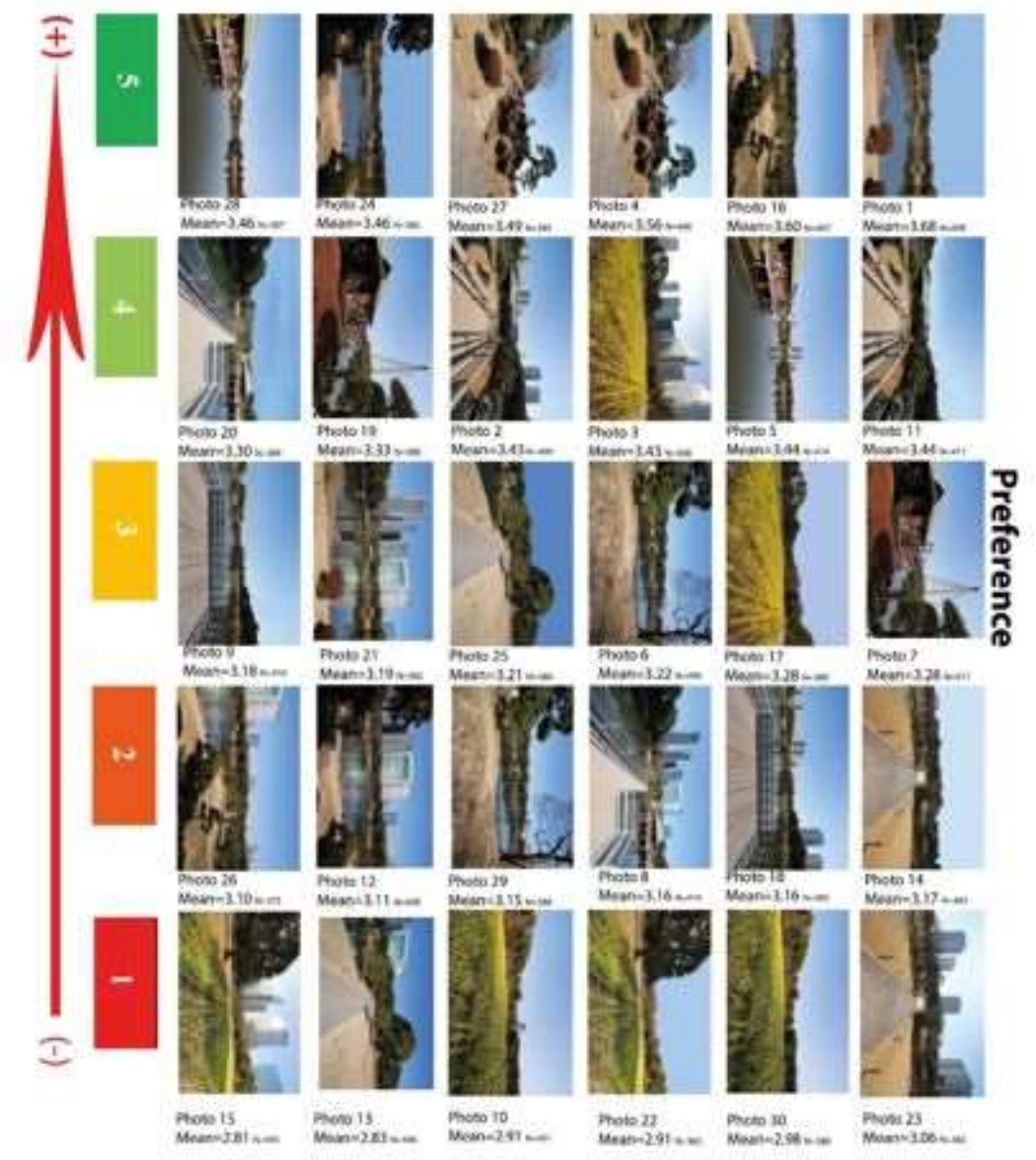

Fig. 2. Sequence and mean scores of the scenes 


\subsection{Comparison between preferences for original photos and simulated photos}

One-way ANOVA tests were done to see the difference between the preferences for original photos (with buildings) and their simulated versions (without buildings). The photos were split into two groups as "original photos" and "simulated photos" for comparison. The results showed that the group of "simulated photos" (3.32) was significantly preferred over "original photos" (3.18) ( $\mathrm{F}=61.7320 \mathrm{df}=11889$ $p<0.001$ ) (Figure 3).

\begin{tabular}{|c|c|c|c|c|c|c|c|c|c|}
\hline Old code & & & & $\mathrm{N}$ & Mean & $\begin{array}{l}\text { Std. } \\
\text { Deviation }\end{array}$ & $d f$ & F Value & $P$ value \\
\hline \multirow{2}{*}{ Comparation of all photos } & \multirow{2}{*}{\multicolumn{2}{|c|}{$\frac{15 \text { photos without building }}{15 \text { pholos with building }}$}} & No building & 5901 & 3.32 & 0.96 & \multirow{2}{*}{11889} & \multirow{2}{*}{61.732} & \multirow{2}{*}{$0.000^{* *}$} \\
\hline & & & Building Exist & 5990 & 3.18 & 0.98 & & & \\
\hline \multirow{2}{*}{$-3 \mathrm{~s}=$} & \multirow[b]{2}{*}{25} & Photo 16 & No building & 407 & 3,60 & 0.95 & \multirow{2}{*}{778} & \multirow{2}{*}{55.812} & \multirow{2}{*}{$0.000^{* *}$} \\
\hline & & Photo 26 & Building Exist & 373 & 3.10 & 0.89 & & & \\
\hline & \multirow[b]{2}{*}{201} & Photo 6 & No building & 406 & 3.22 & 1.02 & \multirow{2}{*}{792} & \multirow{2}{*}{0.957} & \multirow{2}{*}{0.328} \\
\hline 2 & & Photo 29 & Buliding Exist & 388 & 3.15 & 0.98 & & & \\
\hline & \multirow[b]{2}{*}{$=2$} & Photo 1 & No building & 409 & 3.68 & 0.92 & \multirow{2}{*}{789} & \multirow{2}{*}{53.346} & \multirow{2}{*}{$0.000^{* *}$} \\
\hline E & & Photo 21 & Building Exist & 382 & 3.19 & 0.94 & & & \\
\hline \multirow{4}{*}{$y-8$} & \multirow[b]{2}{*}{$y=8$} & Photo 20 & No building & 389 & 3.30 & 0.87 & \multirow{2}{*}{801} & \multirow{2}{*}{4.726} & \multirow{2}{*}{$0.030^{\circ}$} \\
\hline & & Photo 8 & Building Exist & 414 & 3.16 & 1.00 & & & \\
\hline & & Photo 27 & No building & 385 & 3.49 & 0.86 & \multirow{2}{*}{789} & \multirow{2}{*}{1.162} & \multirow{2}{*}{0.281} \\
\hline & & Photo 4 & Building Exist & 406 & 3.56 & 0.92 & & & \\
\hline \multirow{2}{*}{$\frac{3}{2}$} & & Photo 24 & No building & 382 & 3.46 & 0.89 & \multirow{2}{*}{789} & & \\
\hline & & Photo 12 & Building Exist & 409 & 3.11 & 1.05 & & 20.541 & 000 \\
\hline & & Photo 25 & No building & 384 & 3.21 & 0.90 & & 36.468 & $0000+\cdots$ \\
\hline & & Photo 13 & Building Exist & 406 & 2.83 & 0.88 & & 30.400 & 0.000 \\
\hline & & Photo 30 & No building & 388 & 2.98 & 0.98 & 787 & 0.903 & 0.342 \\
\hline & & Photo 10 & Building Exist & 401 & 2.91 & 0.98 & 101 & 0.903 & 0.342 \\
\hline & & Photo 11 & No building & 411 & 3.44 & 0.91 & & & \\
\hline & & Photo 2 & Building Exist & 409 & 3.43 & 0.92 & -818 & 0.038 & 0.845 \\
\hline & & Photo 14 & No building & 401 & 3.17 & 1.00 & & & \\
\hline & & Photo 23 & Building Exist & 382 & 3.06 & 0.90 & 181 & 2.345 & 0.726 \\
\hline & & Photo 22 & No building & 365 & 2.91 & 0.92 & & 0038 & 0155 \\
\hline & & Photo 15 & Building Exist & 405 & 2.81 & 1.01 & 0 & $2.0<0$ & 0.100 \\
\hline & & Photo 28 & No building & 387 & 3.46 & 0.84 & 700 & 0431 & 0718 \\
\hline & & Photo 5 & Building Exist & 414 & 3.44 & 0.95 & 199 & U. 131 & 0.710 \\
\hline & & Photo 17 & No bullding & 389 & 3.28 & 1.00 & & 4325 & v \\
\hline 5. & & Photo 3 & Building Exist & 408 & 3.43 & 1.05 & 190 & 4.0200 & 0.000 \\
\hline & & Photo 19 & No building & 388 & 3.33 & 0.96 & & & \\
\hline & & Photo 7 & Building Exist & 411 & 3.28 & 1.00 & 797 & 0.475 & 0.491 \\
\hline & & Photo 9 & No building & 410 & 3.18 & 1.01 & & 1071 & 790 \\
\hline & & Photo 18 & Building Exist & 382 & 3.16 & 0.92 & & 0.011 & 0.150 \\
\hline
\end{tabular}

* Significant at the $p \leq 0.05$ level

Fig. 3. Comparison of photo pairs

Another one-way ANOVA test was done for each photo pair (original photo and its simulated version). Results showed that the mean preference scores of six photo pairs out of 15 had a significant difference (Figure 3). The most dramatic differences occurred in the photo pairs in which the simulated version (without buildings) of a photo was preferred over the original one (with buildings). The opposite was the case in only one photo pair.

The most dramatic difference occurred in a photo pair in which the simulated version of the photo (Photo 16) with the landscape features of water, trees, paths, groundcovers was significantly more preferred (3.60) than its original version (Photo 26) (3.10) with intensive high-rise buildings ( $F=55.812 \mathrm{df}=778 \mathrm{p}<0.001)$. The second highest difference occurred between the photo with water, traditional structure features, and intensive high-rise buildings at the background (Photo 21) (3.19) and its simulated version without buildings (Photo 1) (3.68) ( $F=53.346 \mathrm{df}=789 \mathrm{p}<0.001$ ). It was followed by the photo pair in which the simulated version (Photo 25) (3.21) that had the scenery of a straight path next to water and towards trees was preferred over its original version (Photo 13) (2.83) which had middle ratio buildings at the background ( $F=36.468 \mathrm{df}=788 \mathrm{p}<0.001)$.

Another significant difference occurred between Photo 12 (3.11) which was the original version having a scenery of water, traditional 
structure, trees and intensive buildings and its simulated version without buildings (Photo 24) (3.46) ( $F=26.541 \mathrm{df}=789 \mathrm{p}<0.001$ ). Finally, it was followed by the photo pair in which the original photo (Photo 8) (3.16) having a bridge with traditional structure, water, trees and intensive high-rise buildings was significantly less preferred than its simulated version (Photo 20) $(3.30)(F=4.726 \mathrm{df}=801 \mathrm{p}<0.05)$. There was only one case where the original photo was preferred over its simulated version. In this pair, the original photo (Photo 3) (3.43) which had the scenery of a field and trees with middle ratio buildings at the background was preferred over its simulated version (Photo 17) (3.28) ( $F=4.325 \mathrm{df}=795 \mathrm{p}<0.05)$.

\subsection{Categorization of the preferences for photos}

Firstly, a reliability analysis was done to calculate the fitness of the model. Results showed that the score of Cronbach Alfa was 0.92 which indicated a good level of fitness value. Then, to reveal the relationships between preferences for each photo and to see hypothetic factors which explain variables of a massive data, factor analysis was done which yielded a five-factor solution (Table 1).

Table 1. Rotated component matrix of factor analysis

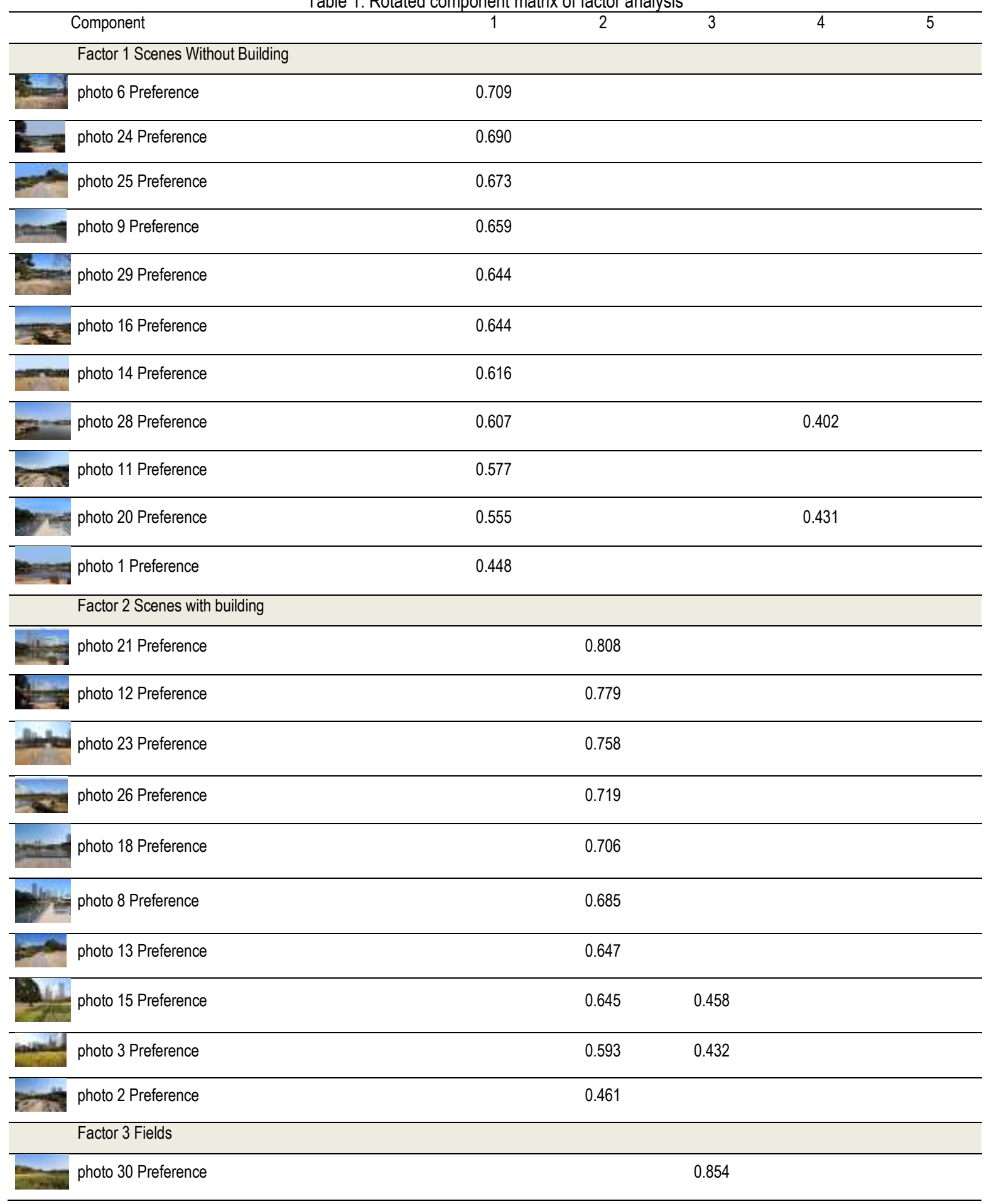


were examined, it was seen that the simulated versions without buildings were significantly preferred over the original photos with buildings. The common feature of these five sceneries was the water element. Besides, the most liked photo (Photo 1) by the mean score had the scenery of a water element. This finding reveals the positive effect of the presence of water on visual preferences which has been proven by previous studies which indicated that the landscapes which contain water element are preferred over the ones without water (Kaplan et al., 1998; Kaplan and Kaplan, 1989). The comparisons between the photo pairs showed that when buildings enter the scenery, the preference gets lower regardless the presence of water element. This situation is considered as an indication of the negative impact of the buildings on the overall scenery of the garden.

The implications of this study are thought to be highly related to the context of sense of place. The skylines shaped by high-rise buildings symbolize power and modernity most of the time. On the other hand, they may cause a feeling of 'placelessness' as those views are indistinguishable from others in appearance. The results showed that the modern high-rise buildings have a negative effect on a traditional heritage garden's authenticity which is also related to its genius loci, or spirit of place. Therefore, this study emphasizes the importance and necessity of planning actions considering place identity.

\subsection{Conclusion}

Whether the beauty is 'in the object' or 'in the eyes of the beholder' is an enduring discussion in the philosophy of aesthetics. This study revealed that the interaction between the subject and object is essential in visual landscape preferences and emphasized the negative effect of the buildings on the garden's scenery by visitor judgments. In this way, the findings of the previous studies on similar issues which were done by objectivists approaches were supported by a subjectivist approach by considering user perceptions. Therefore, it is expected that the results of this study will lead to a strong argument for the implementation of a visual conservation plan for this important heritage garden in the future. Based on the results, it is deduced that the intrusion of external buildings devalues the garden's scenery and its historic spirit. Therefore, comprehensive planning actions should be undertaken to reduce the conspicuousness level of the buildings phase one phase. Especially the sceneries which have water element needs an urgent control since they were found to be the most affected ones from the negative impact of surrounding buildings. In the short term, some actions such as ameliorating the views with green barriers may be applied to reduce the impact of the buildings. In the long term, sustainable solutions such as buffer zones on the surroundings of the garden should be created, and the buildings should be eliminated from the scenery of the garden for sufficient cultural heritage protection. However, the best solutions to protect the scenery of the garden and to enhance its visual landscape quality would be found by user participation in detailed surveys on the issue. It is expected the results which will be derived from the second part of the current study's questionnaire (verbal assessment scale) will determine a course of action in this regard. This study's stimuli is limited with simulated photos with an empty sky and original photos with buildings at the background. Further research may use simulated photos with natural landscape elements such as mountains at the background to analyze the effect of borrowed scenery (Shakkei) technique on visitor preferences. Moreover, further research may consider the perception of the residences of the surrounding buildings on the issue as an approach in terms of participatory planning. It is also suggested that further research should investigate the visual effect of external buildings on other heritage Japanese gardens in similar conditions to reach more comprehensive discussions and generalizable conclusions that would lead us to take actions for the issue. In today's highly economically oriented world, to find solutions to conservation actions, it is highly recommended that the studies should consider user needs and perceptions to raise the awareness towards the importance of cultural heritage sites.

\section{Acknowledgement}

The survey was made possible by the allowance of Tokyo Metropolitan Government Park Association. Support from the manager of Hama-rikyu Gardens, Ms. Nakayama Natsuki, is gratefully acknowledged. We are immensely grateful to Ms. Mayu Tatsuki for preparing the Japanese version of the questionnaire and to Mrs. Pınar Biçer and Mr. Holger Pietrzok for their assistance during the survey. This study was supported by MEXT scholarship.

\section{References}

Abbas, M. Y., Nafisi, N., \& Nafisi, S. (2016). Persian Garden, Cultural Sustainability and Environmental Design case study Shazdeh garden. Procedia-Social and Behavioral Sciences, 222, 510-517.

Arifin N. H, Masuda, T. (1997). The visual impact of building development on Ritsurin garden and its conservation. Landscape Research Japan, J. JILA, 60 (4), $315-323$.

Arifin N. H., Masuda, T. (1998). Visitors' judgments on the scenery of Ritsurin garden. Landscape Research Japan, J. JILA, 61 (3), $259-262$.

Asgarzadeh, M., Lusk, A., Koga, T. \& Hirate, K., (2012). Measuring oppressiveness of streetscapes. Landscape and Urban Planning. 107 (1), 1-11.

Ginting, N., \& Rahman, N. V. (2016). Maimoon Palace Heritage District in Medan, Indonesia: What we preserve and why we preserve?. Procedia-Social and Behavioral Sciences, 222.

Kaplan, R., \& Kaplan, S. (1989). The experience of nature: A psychological perspective. New York: Cambridge University Press.

Kaplan, R., Kaplan, S., \& Ryan, R. (1998). With people in mind: Design and management of everyday nature. Island Press. 
Koizumi, M., \& Ishikawa, M (2007). A study of landscape structure in Dai-sensui and Yokobori area of Hamarikyu Garden [Tokyo, Japan]. Journal of the Japanese Institute of Landscape Architecture, 70 (5), 497-500.

Lin, L., Homma, R., \& Iki, K. (2017). Visual Impact Analysis and Control Method of Building Height for Landscape Preservation of the Traditional Gardens: A Case Study on the Suizenji Jōjuen in Kumamoto City. In Smart Growth and Sustainable Development (pp. 115-125). Springer, Cham.

Omar, D. B., Ibrahim, F.I. B. \& Mohamad N.H.B.N. (2015). Human Interaction in Open Spaces. Procedia-Social and Behavioral Sciences, $201,352-359$.

Othman, N., Mohamed, N., \& Ariffin, M. H. (2015). Landscape aesthetic values and visiting performance in natural outdoor environment. Procedia-Social and Behavioral Sciences, 202, 330-339.

Othman, N., Mohamed, N., Ariffin, M. H., \& Razak, M. A. W. A. (2015). Landscape visual studies in urban setting and its relationship in motivational theory. ProcediaSocial and Behavioral Sciences, 170, 442-451.

Perez, R. I. P. (2014). The historical development of the Tokyo skyline: Timeline and morphology. Journal of Asian Architecture and building engineering, 13 (3), 609615.

Prompayuk, S., \& Chairattananon, P. (2016). Preservation of Cultural Heritage Community: Cases of Thailand and developed countries. Procedia-Social and Behavioral Sciences, 234, 239-243.

Rahman, S. R. A., Ahmad, H., Mohammad, S., \& Rosley, M. S. F. (2015). Perception of green roof as a tool for urban regeneration in a commercial environment: The secret garden, Malaysia. Procedia-Social and Behavioral Sciences, 170, 128-136.

Razak, M. A. W. A., Othman, N., \& Nazir, N. N. M. (2016). Connecting People with Nature: Urban park and human well-being. Procedia-Social and Behavioral Sciences, 222, 476-484.

Sakip, S. R. M., Akhir, N. M., \& Omar, S. S. (2015). Determinant factors of successful public parks in Malaysia. Procedia-Social and Behavioral Sciences, 170, 422-432. Senoglu B., Oktay H.E., \& Kinoshita I. (2018). Visitors' perception of high-rise building effect on the scenery of traditional gardens: a case study in Hama-rikyu Gardens Tokyo. Civil Engineering and Architecture, 6(3), 136-148

Shinji, I., Shimizu, T., \& Takemata, T. (1989). The present situation of landscape destructions on the cultural property gardens in Tokyo. Journal of the Japanese Institute of Landscape Architects, 52 (5) , 43-48.

Shinji, I. (2015). What is a daimyo teien? - The ideal Edo period garden, combining form and function. http://jqrmag.com/en/feature/what-is-a-daimyo-teien-the-ideal-edoperiod-garden-combining-form-and-function. Accessed 18 May 2018

Shinobe, H. (2012). A study on the scenery protection around the garden in the city -case study of five traditional Japanese landscape gardens. Journal of the City Planning Institute of Japan, 47 (3), 625-630.

Thani, S. K. S. O., Ibrahim, N. K., Mohamad, N. H. N., \& Rodzi, N. I. M. (2015). Public Awareness towards Conservation of English Landscape at Taiping Lake Garden, Malaysia. Procedia-Social and Behavioral Sciences, 168, 181-190.

Thani, S. K. S. O., Hashim, N. H. M., \& Ismail, W. H. W. (2016). Surveillance by design: Assessment using principles of Crime Prevention through Environmental Design (CPTED) in urban parks. Procedia-Social and Behavioral Sciences, 234, 506-514.

Türkyılmaz, Ç. C. (2016). Interrelated Values of Cultural Landscapes of Human Settlements: Case of Istanbul. Procedia-Social and Behavioral Sciences, 222, 502-509. Ujang, N., Moulay, A., \& Zakariya, K. (2015). Sense of well-being indicators: Attachment to public parks in Putrajaya, Malaysia. Procedia-Social and Behavioral Sciences, 202, 487-494.

Zakaria, A. Z., Ahmad, S., \& Rashid, M. S. A. (2016). The Importance of Soft and Hard Landscape Elements to the Malays Sub-Ethnic in Perak. Procedia-Social and Behavioral Sciences, 234, 228-238. 